\title{
PATTERNS OF DISTURBED LUNG FUNCTION IN PATIENTS WITH CHRONIC OBSTRUCTIVE VESICULAR EMPHYSEMA
}

BY

\author{
COLIN OGILVIE
}

From the London Hospital

(RECEIVED For PUblication AUGUST 15, 1958)

Emphysema has been defined as a condition in which the alveoli of the lungs are dilated and their walls overdistended (Christie, 1952). In the classification most widely used, emphysema is divided into four groups: (1) Chronic obstructive vesicular emphysema; (2) senile or atrophic emphysema ; (3) acute vesicular emphysema ; and (4) localized or compensatory emphysema. Senile emphysema is often unassociated with symptoms, acute vesicular emphysema is a relatively rare and transient phenomenon, while in compensatory emphysema the primary condition often overshadows the changes attributable to emphysema. The great majority of patients presenting with emphysema in clinical practice must therefore be placed in the first category of chronic obstructive vesicular emphysema. Yet, when these patients come to necropsy, the pathological changes characteristic of this form of the disease are not always found. This was so in nine of Cabot's (1927) 12 patients diagnosed in life as emphysema, whereas only seven of 153 cases diagnosed after death had been recognized during life. Of 72 cases diagnosed at necropsy in Christie's series (Christie, 1952), the presence of dyspnoea during life was mentioned in the case histories of only 35 and, in the great majority, physical signs of emphysema had not been observed. Baldwin, Cournand, and Richards (1949) have recorded a similar lack of correlation between the severity of the functional disturbance in emphysema and the pathological changes in the lungs. One patient in Group IV (their severest functional grade of emphysema) died of cor pulmonale, yet at necropsy little distortion of lung structure could be found.

These observations suggest that the clinical state of emphysema may be allied more closely to disturbances in the function of the lung than to alterations in its structure. An attempt was therefore made to correlate variations in the clinical manifestations of emphysema with differences in the functional disturbance. For this purpose, pulmonary function studies were performed in 33 patients. Nineteen of these were considered to be suffering from chronic vesicular emphysema without radiologically visible bullae and are considered in the present paper. These were divided into two groups, (A) 13 patients with emphysema developing after a long history of chronic bronchitis and (B) six patients with emphysema in whom dyspnoea was the presenting symptom; there was no preceding history of chronic bronchitis. This division was based upon histories obtained by two or three separate observers before pulmonary function tests were performed. In the remaining 14 patients, the chest radiograph revealed air-filled bullae; these are considered in another paper (Ogilvie, 1959).

The criteria for the diagnosis of emphysema were as follows: (1) A history of increasing shortness of breath on exertion, present all the year round. (2) No clinical or radiological evidence of abnormality in the lungs other than signs of bronchitis or overinflation (rhonchi, "barrel" chest, impaired cardiac and liver dullness, flattened diaphragm) ; some or all of these signs were found in every patient. (3) No history or clinical evidence of cardiovascular disease (unless secondary to emphysema) nor any other extrapulmonary cause for dyspnoea. (4) In order to exclude patients with a significant amount of reversible bronchial obstruction, it was also required that an inhalation of $1 \%$ isoprenaline sulphate should not improve the maximum voluntary ventilation by more than $50 \%$ of its original value. The mean increase for this group was in fact $26 \%$.

\section{METHODS}

The following lung function tests were carried out, duplicate measurements being made with the patient at rest in the sitting position: (1) Minute volume of 
respiration. (2) Subdivisions of the lung volumes for which the functional residual capacity and residual volume were measured by a closed-circuit helium dilution method (Bates and Christie, 1950). (3) Maximum voluntary ventilation ("maximum breathing capacity") at a respiratory rate of 80 per minute (M.V.V.80), before and after a five-minute inhalation of $1 \%$ isoprenaline sulphate. (4) Maximum inspiratory and expiratory flow rates (expressed in litres $/ \mathrm{min}$.) derived from the time taken to shift a litre of air (measured from 200-1,200 ml. on the spirogram) with a maximum inspiratory or expiratory effort. A low - resistance Bernstein spirometer (Bernstein, D'Silva, and Mendel, 1952) with a fast recording drum was used to measure M.V.V.80 and maximum flow rates. (5) Alveolar mixing efficiency by the helium technique of Bates and Christie (1950), which gives an indication of the uniformity of alveolar ventilation. (6) Diffusing capacity by the breath-holding carbon monoxide method (Ogilvie, Forster, Blakemore, and Morton, 1957); this measurement reflects changes in the permeability of the tissues interposed between alveolar gas and capillary blood. It would also reflect large changes in the total area of this interface, but it is independent of purely ventilatory abnormalities. (7) Arterial oxygen saturation was measured by the method of Roughton and Scholander (1943). The formulae of Baldwin and others (1948) were used to predict normal lung volumes and maximum voluntary ventilation. The formula of Ogilvie and others (1957) was used to predict the normal diffusing capacity.

\section{Results}

The main differences between the 13 patients in Group A and the six patients in Group B are summarized in the following paragraphs and in $\stackrel{\overrightarrow{\vec{F}}}{\vec{P}}$ Tables I, II, and III.

(1) AgE AND SEX.-The 13 patients in Group $A \frac{\bar{\sigma}}{\bar{c}}$ include nine men and four women with an $\vec{\sigma}$ average age of 43 years (range 20-65 years). The six patients in Group B were all men with an average age of 58 years (range 44-70 years).

(2) Mode of ONSET.-The patients in Group A $\rightarrow$ all gave a long history of chronic or recurring $\vec{\omega}$ bronchitis preceding the appearance of exertional dyspnoea ; five of them had also suffered from $x$ "asthmatic" attacks. None of the patients in $\overrightarrow{+}$ Group B had complained of chronic cough oriv bronchitis before the onset of dyspnoea. Four $\overrightarrow{\vec{\omega}}$ of them dated their symptoms from a severe respiratory infection (acute bronchitis, pneumonia, $\supset$ or influenza) and a fifth first became breathless $\vec{c}$ during the London smog of 1953. The onset of dyspnoea was gradual in only one patient in this ${ }^{\Phi}$ group.

(3) Total Duration of Symptoms. - The average duration of respiratory symptoms was 19.2 years (range 6-43 years) in Group $A$ and $2.7 \%$ years (range 1-4 years) in Group B.

(4) Disability and MoRTALITY.-The average grade of dyspnoea was about the same in the two groups. During a follow-up period of three to $18 \vec{\Rightarrow}$ months, there has been one death (from an acute? respiratory infection) in Group $B$ and none in Group A.

(5) Physical Signs.-The patients in both groups showed the physical signs of bronchitis and $\bar{b}$

TABLE I

CLINICAL DATA ON 19 CASES OF EMPHYSEMA

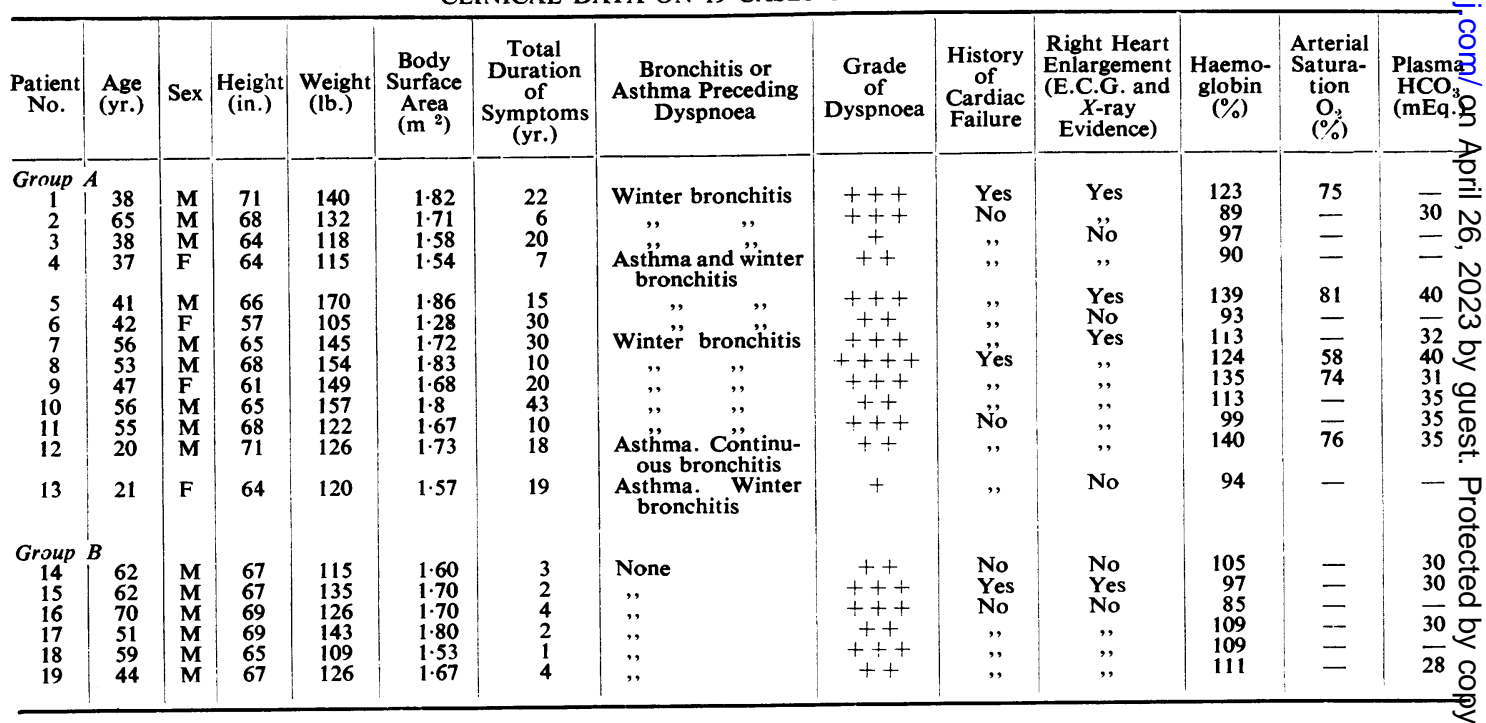


TABLE II

LUNG VOLUMES AND SUBDIVISIONS IN 19 CASES OF EMPHYSEMA

\begin{tabular}{|c|c|c|c|c|c|c|c|c|c|c|}
\hline $\begin{array}{c}\text { Patient } \\
\text { No. }\end{array}$ & $\begin{array}{c}\text { Minute } \\
\text { Volume } \\
\text { (ml.) }\end{array}$ & $\begin{array}{c}\text { Vital } \\
\text { Capacity } \\
\text { (ml.) }\end{array}$ & $\begin{array}{l}\text { V.C. } \\
\text { as \% } \\
\text { Normal }\end{array}$ & $\begin{array}{c}\text { Functional } \\
\text { Residual } \\
\text { Capacity } \\
\text { (ml.) }\end{array}$ & $\begin{array}{c}\text { F.R.C. } \\
\text { as } \% \\
\text { Normal }\end{array}$ & $\begin{array}{c}\text { Residual } \\
\text { Volume } \\
\text { (ml.) }\end{array}$ & $\begin{array}{l}\text { R.V. } \\
\text { as \% } \\
\text { Normal }\end{array}$ & $\begin{array}{c}\text { Total } \\
\text { Lung } \\
\text { Capacity } \\
\text { (ml.) }\end{array}$ & $\begin{array}{c}\text { T.L.C. } \\
\text { as } \% \\
\text { Normal }\end{array}$ & $\begin{array}{c}\text { R.V.I } \\
\text { T.L.C. } \\
\text { Ratio } \\
\%\end{array}$ \\
\hline $\begin{array}{c}\text { Group } A \\
1 \\
2 \\
3 \\
4 \\
5 \\
6 \\
7 \\
8 \\
9 \\
10 \\
11 \\
12 \\
13\end{array}$ & $\begin{array}{r}7,344 \\
10,100 \\
9,350 \\
8,600 \\
10,000 \\
9,500 \\
8,510 \\
7,880 \\
7,950 \\
5,520 \\
8,940 \\
6,240 \\
8,100\end{array}$ & $\begin{array}{l}2,945 \\
3,345 \\
2,750 \\
2,310 \\
3,180 \\
1,660 \\
2,207 \\
1,855 \\
1,440 \\
1,680 \\
2,445 \\
2,980 \\
2,120\end{array}$ & $\begin{array}{l}70 \\
95 \\
73 \\
79 \\
85 \\
65 \\
63 \\
49 \\
54 \\
48 \\
65 \\
65 \\
66\end{array}$ & $\begin{array}{l}5,030 \\
4,760 \\
5,545 \\
4,760 \\
4,490 \\
3,035 \\
6,070 \\
3,900 \\
2,914 \\
5,940 \\
6,268 \\
6,860 \\
4,395\end{array}$ & $\begin{array}{l}189 \\
176 \\
233 \\
257 \\
185 \\
189 \\
223 \\
133 \\
175 \\
218 \\
218 \\
261 \\
240\end{array}$ & $\begin{array}{l}3,965 \\
2,905 \\
4,350 \\
4,010 \\
3,130 \\
2,300 \\
5,418 \\
3,180 \\
2,649 \\
5,560 \\
5,403 \\
5,610 \\
3,795\end{array}$ & $\begin{array}{l}308 \\
185 \\
378 \\
445 \\
275 \\
299 \\
344 \\
188 \\
328 \\
354 \\
324 \\
490 \\
474\end{array}$ & $\begin{array}{l}6,910 \\
6,250 \\
7,100 \\
6,320 \\
6,310 \\
3,990 \\
7,625 \\
5,035 \\
4,089 \\
7,240 \\
7,848 \\
8,590 \\
5,915\end{array}$ & $\begin{array}{r}126 \\
123 \\
144 \\
165 \\
130 \\
120 \\
149 \\
92 \\
118 \\
142 \\
145 \\
150 \\
148\end{array}$ & $\begin{array}{l}57 \\
46 \\
61 \\
63 \\
50 \\
58 \\
71 \\
63 \\
65 \\
77 \\
69 \\
65 \\
64\end{array}$ \\
\hline Mean & 8,300 & 2,380 & 68 & 4,920 & 207 & 4,025 & 338 & 6,400 & 135 & 62 \\
\hline $\begin{array}{c}\text { Group } B \\
14 \\
15 \\
16 \\
17 \\
18 \\
19\end{array}$ & $\begin{array}{r}9,750 \\
14,800 \\
10,570 \\
4,250 \\
14,600 \\
5,280\end{array}$ & $\begin{array}{l}2,195 \\
2,560 \\
2,790 \\
2,600 \\
2,620 \\
2,220\end{array}$ & $\begin{array}{l}62 \\
74 \\
79 \\
65 \\
75 \\
57\end{array}$ & $\begin{array}{l}4,970 \\
5,125 \\
4,640 \\
6,780 \\
4,420 \\
4,030\end{array}$ & $\begin{array}{l}183 \\
192 \\
171 \\
229 \\
165 \\
164\end{array}$ & $\begin{array}{l}4,370 \\
4,060 \\
3,750 \\
6,160 \\
3,020 \\
3,430\end{array}$ & $\begin{array}{l}278 \\
264 \\
239 \\
360 \\
195 \\
288\end{array}$ & $\begin{array}{l}6,565 \\
6,620 \\
6,540 \\
8,760 \\
5,640 \\
5,660\end{array}$ & $\begin{array}{l}128 \\
132 \\
128 \\
158 \\
112 \\
112\end{array}$ & $\begin{array}{l}67 \\
61 \\
57 \\
70 \\
54 \\
61\end{array}$ \\
\hline Mean & 9,875 & 2,500 & 69 & 4,994 & 184 & 4,132 & 271 & 6,632 & 128 & 62 \\
\hline
\end{tabular}

TABLE III

VENTILATORY FUNCTION, MIXING EFFICIENCY, AND CARBON MONOXIDE DIFFUSING CAPACITY IN 19 CASES OF EMPHYSEMA

\begin{tabular}{|c|c|c|c|c|c|c|c|c|}
\hline $\begin{array}{l}\text { Patient } \\
\text { No. }\end{array}$ & $\begin{array}{c}\text { Maximum } \\
\text { Voluntary } \\
\text { Ventilation } \\
\text { (at } 80 \\
\text { resp./min.) } \\
\text { (l.'min.) }\end{array}$ & $\begin{array}{l}\text { M.V.V.80 as } \\
\% \text { Normal }\end{array}$ & $\begin{array}{l}\text { Increase in } \\
\text { M.V.V.80 after } \\
\text { Isoprenaline } \\
\text { (as\% of } \\
\text { Original } \\
\text { Value) }\end{array}$ & $\begin{array}{c}\text { Maximum } \\
\text { Inspiratory } \\
\text { Flow Rate } \\
\text { (1./min.) }\end{array}$ & $\begin{array}{c}\text { Maximum } \\
\text { Expiratory } \\
\text { Flow Rate } \\
\text { (1./min.) }\end{array}$ & $\begin{array}{c}\text { Alveolar } \\
\text { Mixing } \\
\text { Efficiency } \\
(\%)\end{array}$ & $\begin{array}{c}\text { Diffusing } \\
\text { Capacity } \\
\text { (in } \mathrm{ml} / \mathrm{mm} \text {. } \\
\mathrm{Hg} / \mathrm{min} . \text { ) } \\
\text { for } \mathrm{CO}\end{array}$ & $\begin{array}{c}\text { Diffusing } \\
\text { Capacity } \\
\text { as \% } \\
\text { Normal }\end{array}$ \\
\hline $\begin{array}{c}\text { Group } A \\
1 \\
2 \\
3 \\
4 \\
5 \\
6 \\
7 \\
8 \\
9 \\
10 \\
11 \\
12 \\
13\end{array}$ & $\begin{array}{l}38 \\
28 \\
52 \\
40 \\
32 \\
25 \\
30 \\
26 \\
20 \\
24 \\
26 \\
24 \\
24\end{array}$ & $\begin{array}{l}31 \\
31 \\
50 \\
48 \\
26 \\
38 \\
31 \\
24 \\
24 \\
23 \\
27 \\
18 \\
25\end{array}$ & $\begin{array}{r}16 \\
50 \\
12 \\
25 \\
25 \\
48 \\
27 \\
15 \\
45 \\
42 \\
27 \\
0 \\
50\end{array}$ & $\begin{array}{r}200 \\
187 \\
176 \\
135 \\
158 \\
75 \\
194 \\
97 \\
125 \\
154 \\
167 \\
88 \\
120\end{array}$ & $\begin{array}{l}29 \\
33 \\
67 \\
53 \\
29 \\
20 \\
30 \\
21 \\
13 \\
26 \\
17 \\
18 \\
30\end{array}$ & $\begin{array}{l}20 \\
24 \\
26 \\
39 \\
43 \\
13 \\
49 \\
18 \\
30 \\
19 \\
24 \\
27\end{array}$ & $\begin{array}{l}26 \cdot 0 \\
11 \cdot 6 \\
29 \cdot 5 \\
12.4 \\
26 \cdot 6 \\
21 \cdot 6 \\
20.0 \\
10.6 \\
15.9 \\
20 \cdot 2 \\
13.7 \\
10 \cdot 6 \\
19.0\end{array}$ & $\begin{array}{r}95 \\
46 \\
128 \\
56 \\
94 \\
124 \\
78 \\
38 \\
64 \\
74 \\
55 \\
41 \\
83\end{array}$ \\
\hline Mean & 30 & 30 & 29 & 135 & 30 & 28 & $18 \cdot 3$ & 75 \\
\hline $\begin{array}{c}\text { Group } B \\
14 \\
15 \\
16 \\
17 \\
18 \\
19\end{array}$ & $\begin{array}{l}38 \\
40 \\
38 \\
40 \\
38 \\
48\end{array}$ & $\begin{array}{l}44 \\
47 \\
41 \\
37 \\
45 \\
45\end{array}$ & $\begin{array}{r}11 \\
-2 \\
0 \\
25 \\
47 \\
33\end{array}$ & $\begin{array}{l}187 \\
162 \\
193 \\
143 \\
92 \\
200\end{array}$ & $\begin{array}{l}33 \\
58 \\
40 \\
30 \\
36 \\
38\end{array}$ & $\begin{array}{l}35 \\
23 \\
30 \\
39 \\
26 \\
54\end{array}$ & $\begin{array}{c}35 \\
2 \cdot 2 \\
7 \cdot 3 \\
4 \cdot 5 \\
7 \cdot 4 \\
4 \cdot 0\end{array}$ & $\begin{array}{c}7 \cdot 0 \\
29 \\
9 \\
17 \\
33 \\
16\end{array}$ \\
\hline Mean & 40 & 43 & 20 & 163 & 39 & 35 & 5.4 & 22 \\
\hline
\end{tabular}

emphysema in varying degree and no significant differences between the two groups in this respect were detected.

(6) Cardiac Enlargement and Failure.-In Group $A$, one or more episodes of right heart failure had occurred in four patients and another five showed evidence of right heart enlargement without failure. In Group B, one patient had suffered from right heart failure and none of the others had any significant degree of cardiac enlargement.

(7) Blood Changes. - Polycythaemia was present in five patients in Group A, including three of the four patients with a history of cardiac 
failure and two of the five patients with cardiac enlargement without failure. The polycythaemic patients showed a reduced arterial oxygen saturation, and increased plasma bicarbonate levels were noted in six of the eight patients in whom this measurement was made. None of the patients in Group B had polycythaemia and plasma bicarbonate levels were normal.

(8) Pulmonary Function Studies.-The 19 patients in these two groups all showed the ventilatory disturbance characteristic of chronic obstructive vesicular emphysema (Baldwin and others, 1949). Thus in all cases, the maximum voluntary ventilation (M.V.V.80) was reduced to less than $50 \%$ of normal and there was only a slight increase after isoprenaline inhalation. This impairment of the "bellows action" of the lungs was largely due to airway obstruction during expiration: the mean maximum inspiratory flow rate was about one half of the normal value while the mean maximum expiratory flow rate was only one tenth of the normal. The vital capacity was relatively less affected, the mean value for the two groups being $68 \%$ of predicted normal. All patients showed an increase in functional residual capacity, residual volume and (with one exception) total lung capacity. The percentage of the total lung capacity occupied by residual volume was invariably greater than 40 , and greater than 50 in all but one case (normal, less than $35 \%$ ). With one exception, alveolar mixing efficiency was reduced to less than $50 \%$ (normal, greater than $75 \%$ ).

The most variable finding was the pulmonary diffusing capacity and this also provided the most striking difference between Groups A and B. In Group A, the average diffusing capacity was $75 \%$ of predicted normal (range 38-128\%), and seven of the 13 patients fell within the normal range. In Group B, the average diffusing capacity was $22 \%$ of predicted normal (range $9-33 \%$ ) and was reduced to less than one third of the normal in every case. In contrast to this finding, the mean values for M.V.V.80, maximum flow rates, and mixing efficiency were all slightly better and the residual volume (as percentage of predicted normal) smaller in Group $B$ than in Group A. In Fig. 1, diffusing capacity has been plotted against M.V.V.80, each being expressed as a percentage of predicted normal. It will be seen that patients in Group $A$ all lie to the left and patients in Group B to the right of the $45^{\circ}$ line. This indicates that mechanical function is relatively more affected than diffusion in Group A, and diffusion relatively more than mechanical function in Group B.

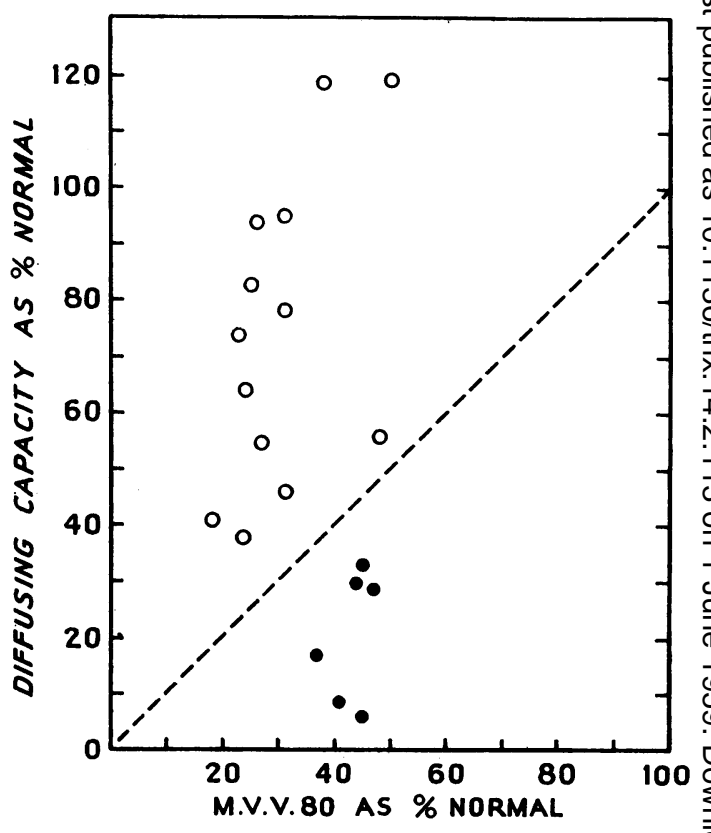

FIG. 1.-Diffusing capacity as percentage of predicted normal plotted against maximum voluntary ventilation (at $80 \mathrm{resp} . / \mathrm{min}$.) as percentage of predicted normal for 19 patients with chronic obstructive vesicular emphysema. The open circles represent patients with a long history of chronic bronchitis (Group A) The closed circles represent patients with no history of chronic bronchitis before the onset of exertional dyspnoea (Group B). These two groups are separated by the $45^{\circ}$ line.

There is no significant correlation in either group between diffusing capacity and other $\frac{}{0}$ measurements of pulmonary function including $x$ vital capacity and the subdivisions of the lung? volumes, ratio of residual volume to total lung. capacity, M.V.V.80, maximum flow rates, response to bronchodilator drugs, or alveolar mixing efficiency. A lack of correlation between the? maximum diffusing capacity for oxygen and $\frac{\mathrm{P}}{\mathrm{O}}$ measurements of mechanical function has also been noted by Shepard, Cohn, Cohen, Armstrong N Carroll, Donoso, and Riley (1955).

In Fig. 2, diffusing capacity (as a percentage of predicted normal) has been plotted against the $e_{\sigma}^{\omega}$ duration of bronchitic symptoms for patients< in both groups. The duration of bronchitice symptoms was derived in each case from historieses recorded by two or three separate observers before pulmonary function studies were performed. It will be seen that there is an inverse relationship between diffusing capacity and the duration of chronic bronchitis. The patients whose diffusing capacity lies within the normal range (over $70 \%$ of predicted normal) all gave a bronchitic historyo of 15 years or more, while all but two of those 


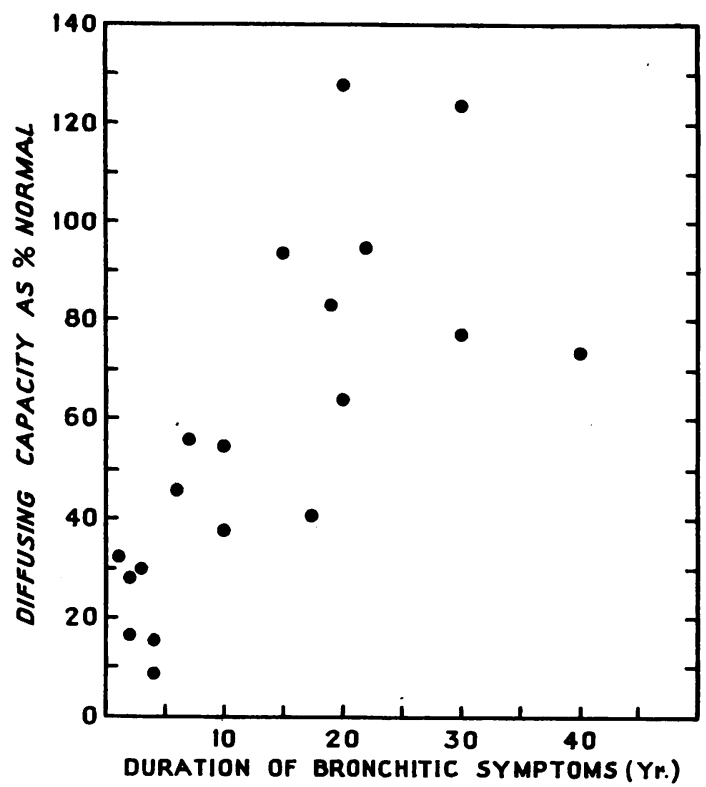

FIG. 2.-Diffusing capacity as percentage of predicted normal plotted against the duration of bronchitic symptoms in years for 19 patients with chronic obstructive vesicular emphysema.

with an abnormal diffusing capacity had symptoms of bronchitis for less than 15 years. The six patients in Group B, whose symptoms had been present for four years or less, all had a diffusing capacity of less than a third of predicted normal.

\section{Illustrative Cases}

Patient No. 5 (Group A), a 41-year-old Jewish butcher, had measles at the age of 3 . He then suffered from "asthma" attacks until he was 12 years old. From the age of 25 , he complained of persistent cough and attacks of bronchitis associated with fever and purulent sputum several times each winter. These attacks sometimes necessitated several weeks in bed. He had noticed increasing dyspnoea and cyanosis on exertion for about five years.

His chest was fixed in the inspiratory position, expiration was prolonged and associated with many rhonchi, and cyanosis was apparent even at rest. There were no clinical signs or history of congestive cardiac failure, but there was radiological evidence of enlargement of the pulmonary artery and the electrocardiogram indicated slight right ventricular preponderance. The chest radiograph showed emphysematous changes in the lungs and a bronchogram revealed no evidence of bronchiectasis. Blood examination showed a considerable degree of polycythaemia, the erythrocyte count being 7.5 million per c.mm., the haemoglobin 20.6 g./100 ml., haematocrit $66 \%$, and red cell volume $3,640 \mathrm{ml}$. (about twice normal). The arterial oxygen saturation was reduced to $81 \%$, increasing to $100 \%$ after breathing oxygen. The high plasma bicarbonate of $40 \mathrm{mEq}$./litre indicated the probability of $\mathrm{CO}_{2}$ retention. Pulmonary function studies (see Tables IF and III) were compatible with severe diffuse obstructive emphysema. The M.V.V.80 was reduced to 32 litres/min. ( $26 \%$ of normal) and showed only a small rise (to 40 litres $/ \mathrm{min}$.) after bronchodilator drugs. The residual volume was increased to between two and three times the predicted normal. Exertion was limited more by leg fatigue than by dyspnoea. Standardized exercise $(350 \mathrm{~kg} .-\mathrm{m} . / \mathrm{min}$. for five minutes) induced an increase in minute volume from $8,250 \mathrm{ml} . / \mathrm{min}$. to $13,700 \mathrm{ml} / \mathrm{min}$. The diffusing capacity was measured on three separate occasions and the values obtained were well within the normal range, 26.1, 28.3, and $31.3 \mathrm{ml} / \mathrm{mm}$. $\mathrm{Hg} / \mathrm{min}$. (predicted normal $=28.2 \mathrm{ml} . / \mathrm{mm}$. $\mathrm{Hg} / \mathrm{min} . \pm 7$ ).

Patient No. 14 (Group B) was a 62-year-old cigarette machine operator. $\mathrm{He}$ had noticed breathlessness on exertion for three years. This had increased so rapidly during the previous six months that he was now only able to do light domestic duties. He had never suffered from asthma or bronchitis nor had he complained of any cough before the onset of the dyspnoea.

On examination there was slight cyanosis on exertion and early clubbing of the fingers. The chest was fixed in the inspiratory position and rhonchi were audible in expiration. The chest radiograph showed emphysematous changes in both lungs, with flattening of the diaphragm. There was no evidence of cardiac enlargement, an electrocardiogram was normal, and there was no polycythaemia. The plasma bicarbonate level was normal. The ventilatory defect was characteristic of emphysema, although less severe than in patient No. 5. The M.V.V.80 was reduced to $44 \%$ of normal and showed an increase from $38 \mathrm{litres} / \mathrm{min}$. to 42 litres $/ \mathrm{min}$. after isoprenaline inhalation. Residual volume was increased to between two and three times the predicted normal. A standardized exercise test $(350 \mathrm{~kg} .-\mathrm{m} . / \mathrm{min}$. for five minutes) induced a greater degree of hyperventilation than in the previous patient, the minute volume increasing from 9,750 to $27,000 \mathrm{ml} . / \mathrm{min}$. The diffusing capacity was reduced to less than one third of predicted normal, $6.3 \mathrm{ml} . / \mathrm{mm}$. $\mathrm{Hg} / \mathrm{min}$. and 7.6 $\mathrm{ml} . / \mathrm{mm}$. $\mathrm{Hg} / \mathrm{min}$. (predicted normal $=23.4 \mathrm{ml} . / \mathrm{mm}$. $\mathrm{Hg} / \min . \pm 7$ ).

\section{Discussion}

The most variable finding among the 19 patients with a clinical and physiological diagnosis of chronic obstructive vesicular emphysema was the diffusing capacity for carbon monoxide. This measurement reflects the permeability of the tissues interposed between alveoli and capillaries and the total area of the alveolo-capillary interface. In seven patients the diffusing capacity was within the normal range, in six patients it was moderately impaired, and in six patients (Group B) it was 
reduced to less than one third of the predicted normal.

The possibility has been considered that either technical errors of measurement or natural fluctuations in diffusing capacity were responsible for some of this variability. The potential sources of error in the breath-holding test have been examined in a previous publication (Ogilvie and others, 1957) when it was shown that a high degree of reproducibility could be obtained. The coefficient of variation of a single estimate (including variation from day to day) was $8.5 \%$. There was no significant difference between the reproducibility in normal subjects and in those with chronic pulmonary disease associated with uneven alveolar ventilation. In the present series, duplicate measurements were made in every case and, in four patients, these were repeated at intervals of from two weeks to 10 months (see Table IV). Fluctuations were small, and most of the duplicate measurements checked within $10 \%$. In one patient with marked expiratory wheezing and rhonchi, an inhalation of isoprenaline sulphate $(1 \%)$ had no significant effect upon the value obtained for diffusing capacity. These observations support previous evidence (Ogilvie and others, 1957) which showed that the breath-holding test provides a measure of diffusing capacity which is reproducible from day to day and is independent of disturbances in alveolar ventilation. The effects of anoxia and of polycythaemia upon the amount of carbon monoxide taken up by the red cells have also been considered as a possible source of error in the measurement of diffusing capacity. It is known that the uptake of carbon monoxide is increased in the presence of anoxia, but this is unlikely to produce more than a $20 \%$ error in measured diffusing capacity (Ogilvie and others, 1957). In patient No. 5, for instance, the diffusing capacity still lies within the normal range after a correction for the low oxygen tension has been made. It is also unlikely that an alteration in the number of red cells significantly affects the uptake of carbon monoxide (Comroe, Forster, Dubois, $\frac{\bar{c}}{\mathrm{c}}$ Briscoe, and Carlsen, 1955), and patients with $\frac{\sigma}{\sigma}$ primary polycythaemia usually have a normal or $\varrho$ low normal diffusing capacity as measured by this $\%$ technique (Ogilvie and others, 1957; Ratto, $\vec{\circ}$ Briscoe, Morton, and Comroe, 1955). Finally, it has been shown that differences between the $\vec{\omega}$ diffusing capacity of different normal subjects is $\stackrel{?}{\rightleftharpoons}$ mainly attributable to variations in size : there is $\vec{x}$ a close correlation between diffusing capacity and $\vec{A}$ body surface area (Ogilvie and others, 1957). i Differences of sex and age appear to be of less $\overrightarrow{-}$ significance. It is therefore improbable that either $\omega$ technical inaccuracies or physiological variations $ᄋ$ in diffusing capacity could account for the wide variability observed between different patients $气$ with emphysema in the present series.

It is known that the diffusing capacity increases $\overrightarrow{0}$ on exercise and this has been attributed to 0 an expansion of the pulmonary capillary bed $\square$ consequent upon an increased blood flow. The possibility that variations in pulmonary blood flow in emphysema may contribute to the variability of the diffusing capacity was therefore $\mathbb{D}$ considered. The resting oxygen uptake (which should be proportionate to pulmonary blood flow)응 of the patients with emphysema in the present series was invariably found to lie between 150 and $350 \mathrm{ml}$. per minute. Within this range, no detectable variations in diffusing capacity would $\vec{\circ}$ be expected (Ogilvie and others, 1957). In this connexion, it is of interest that Shepard and others (1955) found that six of 27 patients with 3 . emphysema (or six of 22 patients who were ablei to exercise sufficiently) showed a normal maximum diffusing capacity on exercise. Their results are obviously independent of variations in resting? pulmonary blood flow, and the proportion of patients proved to have a normal diffusing capacity is similar to that in the present series.

TABLE IV

REPEATED MEASUREMENTS OF CARBON MONOXIDE DIFFUSING CAPACITY IN FOUR CASES OF EMPHYSEMA

\begin{tabular}{|c|c|c|c|c|c|c|c|c|c|}
\hline $\begin{array}{l}\text { Patient } \\
\text { No. }\end{array}$ & $\begin{array}{l}\text { Diffusing } \\
\text { Capacity } \\
\text { (ml./mm. } \\
\mathrm{Hg} / \mathrm{min} \text {.) }\end{array}$ & Interval & $\begin{array}{l}\text { Diffusing } \\
\text { Capacity } \\
\text { (ml./mm. } \\
\mathrm{Hg}^{\prime} / \mathrm{min} . \text { ) }\end{array}$ & Interval & $\begin{array}{l}\text { Diffusing } \\
\text { Capacity } \\
\text { (ml. } / \text { mm. } \\
\mathrm{Hg} / \mathrm{min} . \text { ) }\end{array}$ & Interval & $\begin{array}{l}\text { Diffusing } \\
\text { Capacity } \\
\text { (ml./mm. } \\
\mathrm{Hg} / \mathrm{min} \text {.) }\end{array}$ & Interval & $\begin{array}{l}\text { Diffusing } \\
\text { Capacity } \\
\text { (ml./mm. } \\
\mathrm{Hg} / \mathrm{min} . \text { ) }\end{array}$ \\
\hline & $\begin{array}{l}15.0 \\
16.0\end{array}$ & & $\begin{array}{l}19.0 \\
17.9\end{array}$ & 1 week & $\begin{array}{l}15 \cdot 5 \\
16 \cdot 2\end{array}$ & 4 months & 16.6 & 8 months & $\begin{array}{l}12.9 \\
13.7\end{array}$ \\
\hline 5 & $\begin{array}{r}28.3 \\
* 31.3\end{array}$ & $2 \quad$, & *26.1 & & & & & & \\
\hline 19 & $1 \cdot 2$ & 9 , , & $\begin{array}{r}3.9 \\
4.1\end{array}$ & & & & & & \\
\hline 28 & $\begin{array}{l}5.7 \\
5.7\end{array}$ & 10 months & $\begin{array}{l}4.5 \\
2 \cdot 0\end{array}$ & & & & & & \\
\hline
\end{tabular}


It has been shown that the emphysematous patients with evidence of severe damage to the diffusing surface of the lung (Group B) actually gave a shorter history of bronchitic symptoms and showed a lesser degree of ventilatory dysfunction than those with a moderately impaired or normal diffusion (Group A). The pathological findings of Heppleston (1953) and of Leopold and Gough (1957) may be relevant to this observation. In a study of the micro-anatomy of chronic vesicular emphysema, Heppleston noted that the dilatation of alveolar ducts and more distal parts of the primary lobule characteristic of this condition did not necessarily result in destruction of lung tissue. Leopold and Gough found that the extreme overinflation associated with congenital obstructive lobar emphysema did not cause disruption of intervening air-space walls; the general structure of the lung remained intact. They concluded that normal tissues can withstand an extreme degree of overinflation and that mechanical stresses alone may not be capable of disrupting healthy lung tissue. One hundred and forty examples of chronic vesicular emphysema from the general population were also examined at necropsy by Leopold and Gough. They found evidence of chronic bronchitis and of a uniform dilatation of the distal air-spaces in all these cases, but actual tissue destruction was apparent in only 75 . These 75 cases all showed a severe bronchiolitis with inflammatory changes involving the adjacent alveoli and large emphysematous spaces in the centre of the lobule. These spaces were derived from the dilatation of respiratory bronchioles and the surrounding alveoli whose walls were weakened and disrupted by the inflammatory process. The authors produced evidence to show that this "centrilobular" form of emphysema was the result of inflammation rather than of airway obstruction; the bronchiole supplying the emphysematous areas was more often dilated than narrowed. The irregular distribution throughout the lungs further suggested that the stress of chronic cough was not responsible for the lesions in this form of emphysema. The pathological evidence thus favours the existence of at least two distinct processes in the pathogenesis of emphysema: (1) Generalized overinflation, without disruption of alveolar walls, which probably results from expiratory bronchial obstruction due to bronchitis, and (2) a "centrilobular" inflammatory process, which is found together with the generalized form of emphysema, and which does produce actual destruction of respiratory tissue.
The findings in the present investigation provide some physiological support for the existence of two such processes. The inverse relationship between the duration of bronchitic symptoms and the severity of damage to the diffusing surface of the lung (see Fig. 2) can best be explained on the assumption that two separate factors are concerned in the production of emphysema. This inverse relationship suggests (1) that chronic bronchitis alone takes many years to produce the clinical and physiological state of emphysema and does not itself cause damage to the diffusing surface of the lung, and (2) that the factor concerned in the impairment of diffusion is associated with a much more rapidly developing form of emphysema. Possible factors are the peribronchiolar inflammatory process postulated by Leopold and Gough and an increased vulnerability of the pulmonary tissues in which age may play a part. The fact that no patients with a severe impairment of diffusion and a long history of respiratory symptoms were encountered in this series may be explained by the observation of Bates, Knott, and Christie (1956) that patients with a low diffusing capacity tend to die at an early stage of the disease.

It should be emphasized that the more severe impairment of diffusion among patients without a history of chronic bronchitis (Group B) cannot be attributed simply to their having reached a more advanced stage of emphysema than the patients in Group A. The degree of disability was similar in the two groups and the disturbance in ventilatory function was actually greater in Group A (see Table III and Fig. 1). Furthermore, the incidence of cardiac complications and of polycythaemia was also greater in Group A and bore no relation to the level of the diffusing capacity. This could be attributed to the fact that anoxia, due to the severe ventilatory disturbance, had been present for a much longer time and that $\mathrm{CO}_{2}$ retention was more severe than in Group B. The latter observation is in keeping with the fact (Comroe and others, 1955) that $\mathrm{CO}_{2}$ retention is the consequence of inadequate alveolar ventilation and rarely if ever results solely from a barrier to diffusion.

The finding of a normal diffusing capacity in the presence of severe emphysema with poly cythaemia and cor pulmonale (patients Nos. 1, 5 , and 10) is in keeping with the necropsy observation of Baldwin and others (1949) in one of their patients. This patient presented at the age of 38 with a 10-year history of severe bronchitis and progressive exertional dyspnoea. 
Cyanosis and ankle oedema had been present for six years and there had been several episodes of right heart failure. Laboratory studies revealed severe emphysema associated with arterial anoxia, $\mathrm{CO}_{2}$ retention, and polycythaemia. The patient did not die until nine years later when, at necropsy, little distortion of lung structure could be found. There was a minimal decrease in elastic tissue and the arterioles and precapillaries had as a rule normal walls. The authors postulated that arterial anoxia in this case had resulted mainly from disturbances in alveolar ventilation. They suggested that hypervolaemia and increased blood viscosity due to polycythaemia had played an important part in the development of cor pulmonale and that structural shrinkage of the pulmonary capillary bed contributed little. They noted that polycythaemia was associated with chronic cardiac failure in most of their patients regardless of the severity of anoxia. This association was also found in the present investigation, regardless of the severity of impaired diffusion (Table I).

There is therefore both pathological and physiological evidence to suggest that the clinical state of severe emphysema can exist in the absence of detectable damage to the alveolar or diffusing surface of the lung. This concept has an important bearing upon the prognosis of certain forms of emphysema and justifies a more optimistic approach to treatment. The prognosis is admittedly grave in those patients-usually older men-in whom emphysema develops rapidly with little antecedent history of chronic bronchitis (Group B). It is in this group that the diffusing capacity-a measure of the integrity of the alveolar tissues of the lung-is severely impaired, and this, as Bates and others (1955) have shown, portends a fatal outcome at an early stage. The only death so far among patients in the present series did occur in Group B. In this group, one would expect to find irreversible damage to the structure of the lung, such as the inflammatory centrilobular lesion described by Leopold and Gough, and little response to treatment would be expected. However, it is possible that emphysema of this type can be prevented by the more intensive treatment of acute respiratory infections in older men. Four of the six patients in Group B developed symptoms of emphysema immediately after an acute respiratory infection, before which they had been in perfect health. On the other hand, the prognosis among patients in Group A may well be better than the severity of their disability and the frequency of cardiac complications would suggest. The patient cited by Baldwin lived for 15 years after persistent $\stackrel{\overrightarrow{\bar{S}}}{\stackrel{\overrightarrow{3}}{9}}$ cyanosis and evidence of right heart failure were $?$ first recorded. Patient No. 9 in the present series $\underline{\underline{D}}$ has now been observed for seven years since $\frac{\bar{\rho}}{\frac{1}{}}$ persistent cyanosis at rest, polycythaemia, and $\stackrel{\varnothing}{\varrho}$ signs of right heart failure were first observed. During the last 13 months of this period, duplicate measurements of diffusing capacity repeated on five separate occasions, with the exception of the $\vec{\omega}$ last measurement, have been only slightly below ${ }^{\circ}$ the normal range $(18-32 \mathrm{ml} . / \mathrm{mm}$. $\mathrm{Hg} / \mathrm{min}$.) (see $\vec{x}$ Table IV). Recurrent pulmonary infections and episodes of right heart failure have been $\vec{i}$ successfully treated with antibiotics, bronchodilator drugs, oxygen, venesection, digitalis, and $\vec{\omega}$ mercurial diuretics. Apart from these episodes, the patient is still able to do light housework and even to shop for her family. The remarkable $\subseteq$ ability of patients in this group to recover from serious infective and congestive complications $\vec{A}$ when these are adequately treated emphasizes that 0 it is the function rather than the structure of the lung and pulmonary circulation which is at fault. An optimistic attitude is therefore justified, particularly if this is translated into the vigorouso treatment of emphysematous patients who are $\frac{0}{\mathbb{D}}$ alleged to be dying of heart failure or $a \varrho$ "terminal" respiratory infection.

\section{SUMMARY}

The lung volumes, the mechanical and? ventilatory function of the lungs, and the pulmonary diffusing capacity were measured in음 19 patients with chronic obstructive vesiculary emphysema.

The patients in whom emphysema developed rapidly without a preceding history of chronico bronchitis (Group B) showed severe damage to the diffusing surface of the lung as measured by윽 the diffusing capacity for carbon monoxide.

In the patients in whom emphysema developed․ㅡㄹ. after many years of chronic bronchitis (Group A), N the ventilatory disability and the incidence of cardiac complications were even greater than in Group B, but the diffusing capacity was normale or only moderately impaired.

It is therefore suggested that at least twoo separate factors are concerned in the pathogenesiso of the disease and that the one associated with ${ }^{\circ}$ chronic bronchitis can produce the clinical and physiological picture of emphysema and coro pulmonale without detectable damage to the alveolar and capillary tissues of the lung.

The relevance of these observations to theo pathology, prognosis, and treatment of emphysema is discussed. 
I am grateful to Dr. Kenneth Perry, Dr. Lloyd Rusby, and Professor Clifford Wilson for their constant interest and helpful advice during the preparation of this paper. I am also indebted to Dr. David Verel for the haematological measurements.

\section{REFERENCES}

Baldwin, E. deF., Cournand, A., and Richards, D. W., Jr. (1948). Medicine (Baltimore), 27, 243.

- (1949). Ibid., 28, 201

Bates, D. V., and Christie, R. V. (1950). Clin. Sci., 9, 17.

Knott, J. M. S., and Christie, R. V. (1956). Quart. J. Med., $25,137$.

Bernstein, L., D’Silva, J. L., and Mendel, D. (1952). Thorax, 7, 255.

Cabot, R. C. (1927). Physical Diagnosis, 9th ed. Williams and Wilkins, Baltimore.
Christie, R. V. (1952). In Diseases of the Chest, edited by Marshall, G., and Perry, K. M. A., Vol. 2, p. 101. Butterworths, London. Comroe, J. H., Forster, R. E., Dubois, A. B., Briscoe, W. A., and Carlsen, E. (1955). The Lung. The Year Book Publishers, Chicago.

Heppleston, A. G. (1953). J. Path. Bact., 66, 235.

Leopold, J. G., and Gough, J. (1957). Thorax, 12, 219.

Ogilvie, C. M. (1959). Thorax. To be published.

Forster, R. E., Blakemore, W. S., and Morton, J. W. (1957). J. clin. Invest., 36, 1.

Ratto, O., Briscoe, W. A., Morton, J. W., and Comroe, J. H. (1955). Amer. J. Med., 19, 958.

Roughton, F. J. W., and Scholander, P. F. (1943). J. Biol. Chem., $148,541$.

Shepard, R. H., Cohn, J. E., Cohen, G., Armstrong, B. W., Carroll, D. G., Donoso, H., and Riley, R. L. (1955). Amer. Rev. Tuberc., 71, 249. 